\title{
Timothy Hay with a Low Dietary Cation-Anion Difference Improves Calcium Homeostasis in Periparturient Holstein Cows
}

\author{
G. B. Penner, ${ }^{*}$ G. F. Tremblay, $†$ T. Dow, $\ddagger$ and M. Oba ${ }^{\star 1}$ \\ ${ }^{*}$ Department of Agricultural, Food and Nutritional Science, University of Alberta, Edmonton, Alberta, T6G 2P5, Canada \\ †Agriculture and Agri-Food Canada, Soils and Crops Research and Development Centre, Québec, Québec, G1V 2J3, Canada \\ $\ddagger$ Alberta Agriculture and Food, Lethbridge, Alberta, T1J 4V6, Canada
}

\begin{abstract}
The current study was undertaken to evaluate the effects of feeding timothy (Phleum pratense L.) hay differing in dietary cation-anion difference (DCAD) on the capability of cows to maintain calcium homeostasis around parturition. We hypothesized that feeding lowDCAD timothy hay during the prepartum period would induce a mild metabolic acidosis prepartum and improve calcium homeostasis postpartum with no effect on dry matter intake. Forty-one dry pregnant Holstein cows entering their second lactation or greater were used in a randomized complete block design. Timothy hay was obtained from an established timothy stand under a pivot irrigation system. Low-DCAD timothy hay was produced by fertilizing the area between the second and third pivot towers at a rate of $224 \mathrm{~kg}$ of $\mathrm{CaCl}_{2} / \mathrm{ha}$, and control timothy hay (high DCAD) was grown on the area between the fourth and fifth pivot towers of the same field. The chloride concentration was 1.07 and $0.15 \%$ on a dry matter (DM) basis, and the DCAD was 1.2 and $21.6 \mathrm{mEq} / 100 \mathrm{~g}$ of DM for the low- and high-DCAD timothy hay, respectively. Experimental diets, containing timothy hay at $63 \%$ of dietary $\mathrm{DM}$, were fed ad libitum starting $30 \mathrm{~d}$ before the expected calving date. The DCAD values were 1.6 vs. 14.5 $\mathrm{mEq} / 100 \mathrm{~g}$ of $\mathrm{DM}$ for the low- and high-DCAD timothybased diets, respectively. At the beginning of the study, urine $\mathrm{pH}$ and blood bicarbonate concentration averaged $8.22 \pm 0.06$ and $28.5 \pm 0.3 \mathrm{mM}$, respectively. The lowDCAD timothy diet decreased urine $\mathrm{pH}$ compared with the high-DCAD timothy diet on $\mathrm{d} 21$ (7.75 vs. 8.31), d 14 (7.69 vs. 8.22), and d 7 (7.50 vs. 8.19) before calving, and it also decreased the prepartum blood bicarbonate concentration by $2 \mathrm{~m} M$. In addition, cows fed the lowDCAD timothy diet had greater blood ionized calcium concentration prepartum (1.22 vs. $1.19 \mathrm{mM}$ ), greater blood ionized calcium concentration at 0 and $8 \mathrm{~h}$ after
\end{abstract}

Received November 20, 2007.

Accepted January 20, 2008.

${ }^{1}$ Corresponding author: masahito.oba@afhe.ualberta.ca calving, and similar prepartum dry matter intake. These results indicate that timothy hay differing in DCAD affects the acid-base balance of periparturient dairy cows, and that low-DCAD timothy hay improves calcium homeostasis postpartum with no negative effect on dry matter intake.

Key words: dairy cow, dietary cation-anion difference, calcium homeostasis, hypocalcemia

\section{INTRODUCTION}

Parturient paresis is a metabolic disorder caused by the inability of a cow to meet the calcium demands of colostrum production via dietary calcium absorption, bone calcium mobilization, and renal calcium resorption. The resulting hypocalcemic condition affects the health and profitability of transition dairy cows. In a controlled research setting, prevalence rates for clinical hypocalcemia ranged between 13 and 20\%, with an additional 20 and 53\% experiencing subclinical hypocalcemia, for cows fed prepartum diets containing a DCAD of -7 and $+30 \mathrm{mEq} / 100 \mathrm{~g}$ of DM, respectively (Joyce et al., 1997). Block (1984) conducted a 2-yr crossover study in which cows were fed a prepartum diet containing DCAD of either $3.3 \mathrm{mEq} / 100 \mathrm{~g}$ or $-1.3 \mathrm{mEq} / 100 \mathrm{~g}$ of DM and reported no incidence of milk fever for cows fed the low-DCAD diet, whereas feeding the positive DCAD diet resulted in an incidence of milk fever of nearly $50 \%$. Further, cows fed the prepartum diet containing a DCAD of $-1.3 \mathrm{mEq} / 100$ g produced nearly 500 $\mathrm{kg}$ more milk per lactation than cows receiving the diet containing a DCAD of $3.3 \mathrm{mEq} / 100 \mathrm{~g}$. As such, reducing the prevalence of hypocalcemia has the potential to improve both animal health and productivity.

Lowering the DCAD of prepartum diets has been shown to improve calcium homeostasis during the periparturient period. Diets containing anionic salts or an acidifying agent cause a compensated metabolic acidosis improving parathyroid hormone (PTH) sensitivity, increasing 1,25-dihydroxyvitamin $\mathrm{D}\left[\mathbf{1 , 2 5 - ( \mathbf { O H } ) _ { 2 }} \mathbf{D}\right]$ concentration per unit of PTH (Goff et al., 1991; Block, 1994), and improving renal resorption, osteoclastic mo- 
Table 1. Nutrient composition of the low- and high-DCAD timothy hays

\begin{tabular}{|c|c|c|c|c|}
\hline \multirow[b]{2}{*}{ Nutrient } & \multicolumn{4}{|c|}{ Timothy hay } \\
\hline & Low DCAD & SD & High DCAD & SD \\
\hline $\mathrm{DM}, \%$ & 89.7 & 1.5 & 89.7 & 1.6 \\
\hline $\mathrm{CP}, \%$ of $\mathrm{DM}$ & 7.1 & 0.5 & 7.7 & 0.8 \\
\hline $\mathrm{ADF}, \%$ of $\mathrm{DM}$ & 43.4 & 0.8 & 41.7 & 1.0 \\
\hline $\mathrm{NDF}, \%$ of DM & 69.0 & 1.7 & 65.6 & 1.9 \\
\hline Ash, \% of DM & 5.5 & 0.3 & 5.6 & 0.6 \\
\hline $\mathrm{Ca}, \%$ of $\mathrm{DM}$ & 0.32 & 0.06 & 0.30 & 0.04 \\
\hline $\mathrm{P}, \%$ of $\mathrm{DM}$ & 0.13 & 0.01 & 0.14 & 0.01 \\
\hline $\mathrm{Na}, \%$ of $\mathrm{DM}$ & $<0.01$ & 0.00 & $<0.01$ & 0.01 \\
\hline $\mathrm{K}, \%$ of $\mathrm{DM}$ & 1.48 & 0.05 & 1.28 & 0.08 \\
\hline $\mathrm{Mg}, \%$ of $\mathrm{DM}$ & 0.12 & 0.01 & 0.12 & 0.02 \\
\hline $\mathrm{S}, \%$ of DM & 0.11 & 0.01 & 0.12 & 0.01 \\
\hline $\mathrm{Cl}, \%$ of $\mathrm{DM}$ & 1.07 & 0.06 & 0.15 & 0.03 \\
\hline $\mathrm{Fe}, \mathrm{mg} / \mathrm{kg}$ & 44.3 & 9.7 & 112.0 & 86.6 \\
\hline $\mathrm{Mn}, \mathrm{mg} / \mathrm{kg}$ & 22.5 & 2.6 & 30.5 & 2.5 \\
\hline $\mathrm{Zn}, \mathrm{mg} / \mathrm{kg}$ & 24.8 & 12.9 & 24.5 & 2.6 \\
\hline $\mathrm{Cu}, \mathrm{mg} / \mathrm{kg}$ & 7.3 & 1.0 & 7.3 & 1.0 \\
\hline $\mathrm{DCAD},{ }^{1} \mathrm{mEq} / 100 \mathrm{~g}$ of $\mathrm{DM}$ & 1.2 & 2.3 & 21.6 & 1.8 \\
\hline
\end{tabular}

${ }^{1}$ Calculated as $\left(\mathrm{Na}^{+}+\mathrm{K}^{+}\right)-\left(\mathrm{C}^{-}+\mathrm{S}^{2-}\right)$ (Ender et al., 1971).

bilization, and intestinal absorption of calcium (Horst et al., 1997). Selection of forage species and fertilization with chloride may be a possible alternative to decrease the DCAD. Recently, Tremblay et al. (2006) evaluated the DCAD of 5 cool-season grasses grown on various soils and reported that timothy hay had the lowest DCAD due to low potassium concentration. Subsequent studies have consistently demonstrated that the DCAD of timothy hay can be further reduced when it is fertilized with various sources of chloride (Oba et al., 2007; Pelletier et al., 2007, 2008). However, data are limiting on whether timothy hay with a low DCAD can improve the cow's ability to maintain calcium homeostasis around parturition.

Feeding anionic salts or acidifying agents often decreases DMI predisposing animals to other disorders such as displaced abomasum and ketosis. Charbonneau et al. (2006a) conducted a meta-analysis encompassing 22 published studies and reported a positive linear relationship between the DCAD calculated as $\left(\mathrm{Na}^{+}+\mathrm{K}^{+}\right)-$ $\left(\mathrm{Cl}^{-}+0.6 \mathrm{~S}^{2-}\right)$ and DMI $\left(P<0.01 ; \mathrm{R}^{2}=0.66\right)$. However, a recent study (Charbonneau et al., 2008) comparing a control diet $(\mathrm{DCAD}=29.6 \mathrm{mEq} / 100 \mathrm{~g}$ of $\mathrm{DM})$, a diet containing timothy hay with a low DCAD $(-2.4 \mathrm{mEq} /$ $100 \mathrm{~g}$ of DM), and the control diet supplemented with $\mathrm{HCl}(-1.9 \mathrm{mEq} / 100 \mathrm{~g}$ of DM) suggests that the methods to decrease the DCAD (hay vs. $\mathrm{HCl}$ supplement) may have an impact on DMI. In that study, feeding cows with the low-DCAD timothy hay diet did not decrease DMI relative to the control; however, feeding cows with the $\mathrm{HCl}$-supplemented diet tended to decrease DMI relative to the low-DCAD timothy hay diet. Thus, further research is warranted to investigate the effect of lowDCAD forages on DMI.
The objective of the current study was to evaluate the effects of feeding timothy (Phleum pratense L.) hay differing in DCAD on DMI and the capability of cows to maintain calcium homeostasis around parturition.

\section{MATERIALS AND METHODS}

This experiment was conducted between October 2006 and February 2007 at the University of Alberta Dairy Research and Technology Centre (Edmonton, Alberta, Canada). All procedures were approved by the Faculty Animal Policy and Welfare Committee at the University of Alberta and were performed according to the guidelines of the Canadian Council of Animal Care (Ottawa, Ontario, Canada).

\section{Experimental Design and Dietary Treatments}

Timothy hay was obtained from an established timothy stand under a pivot irrigation system near Lethbridge (Alberta, Canada). Soil K content of the field was $486 \mathrm{~kg} / \mathrm{ha}$. The field was fertilized with $112 \mathrm{~kg}$ of N/ha as urea, and $39 \mathrm{~kg}$ of $\mathrm{P} / \mathrm{ha}$ as monoammonium phosphate on April 15, 2006. In addition, anhydrous calcium chloride was applied using a fertilizer broadcaster to the area between the second and third pivot towers at a rate of $224 \mathrm{~kg} / \mathrm{ha}$ ( $143 \mathrm{~kg}$ of Cl/ha) on April 15 to produce the low-DCAD timothy hay. Control timothy hay (high-DCAD) was grown on the area between the fourth and fifth pivot towers of the same field. The hay was harvested on July 8 as small rectangular bales weighing approximately $27 \mathrm{~kg}$ each, transported to the University of Alberta (Edmonton, Alberta, Canada), and stored in a covered shelter. The nutrient and min- 
Table 2. The ingredient and nutrient composition of the low- and high-DCAD diets

\begin{tabular}{lcc}
\hline & \multicolumn{2}{c}{ Dietary treatment } \\
\cline { 2 - 3 } Ingredient, \% of DM & Low DCAD & High DCAD \\
\hline Low-DCAD timothy hay & 63.3 & - \\
High-DCAD timothy hay & - & 63.3 \\
Concentrate mix 1,2 & 36.7 & 36.7 \\
Nutrient & & \\
CP, \% of DM & 12.5 & 12.9 \\
ADF, \% of DM & 30.6 & 29.5 \\
NDF, \% of DM & 49.6 & 47.4 \\
Ash, \% of DM & 7.0 & 7.1 \\
Ca, \% of DM & 0.74 & 0.72 \\
P, \% of DM & 0.35 & 0.35 \\
Na, \% of DM & 0.04 & 0.04 \\
K, \% of DM & 1.31 & 1.18 \\
Mg, \% of DM & 0.35 & 0.35 \\
S, \% of DM & 0.20 & 0.21 \\
Cl, \% of DM & 0.75 & 0.17 \\
Fe, mg/kg & 427 & 470 \\
Mn, mg/kg & 105 & 110 \\
Zn, mg/kg & 184 & 183 \\
Cu, mg/kg & 30 & 30.3 \\
DCAD, ${ }^{3}$ mEq/100 g of DM & 1.6 & 14.5 \\
\hline
\end{tabular}

${ }^{1}$ Contained $24.0 \%$ ground corn grain, $20.0 \%$ rolled corn grain, $20.0 \%$ soybean meal, $15.0 \%$ dehydrated beet pulp, $4.0 \%$ corn gluten meal, $4.0 \%$ SoyPlus (West Central Coop., Ralston, IA), 3.0\% rolled barley, $2.8 \%$ mineral and vitamin mix, $2.5 \%$ molasses, $2.0 \%$ canola meal, $1.8 \%$ limestone, and $1.0 \%$ canola oil on an as fed basis.

${ }^{2}$ Nutrient composition on a DM basis, $21.8 \% \mathrm{CP}, 8.6 \% \mathrm{ADF}, 16.1 \%$ $\mathrm{NDF}, 9.6 \%$ ash, $1.46 \% \mathrm{Ca}, 0.73 \% \mathrm{P}, 0.10 \% \mathrm{Na}, 1.03 \% \mathrm{~K}, 0.74 \% \mathrm{Mg}$, $0.37 \% \mathrm{~S}, 0.20 \% \mathrm{Cl}, 1,087 \mathrm{ppm}$ of $\mathrm{Fe}, 248 \mathrm{ppm}$ of $\mathrm{Mn}, 458 \mathrm{ppm}$ of $\mathrm{Zn}$, $70 \mathrm{ppm}$ of $\mathrm{Cu}, 25,000 \mathrm{IU} / \mathrm{kg}$ of vitamin A, 6,000 IU/kg of vitamin D, $360 \mathrm{IU} / \mathrm{kg}$ of vitamin $\mathrm{E}$, and $2.14 \mathrm{mEq} / 100 \mathrm{~g}$ of DCAD.

${ }^{3}$ Calculated as $\left(\mathrm{Na}^{+}+\mathrm{K}^{+}\right)-\left(\mathrm{Cl}^{-}+\mathrm{S}^{-2}\right)$ (Ender et al., 1971).

eral composition of the low-DCAD and high-DCAD timothy hay fed during the animal study $(\mathrm{n}=4$; samples were collected twice weekly and composited monthly) are listed in Table 1.

Forty-one Holstein cows entering their second or greater parity (mean parity \pm standard deviation; 2.95 \pm 1.14 ) were blocked by parity and then randomly assigned to 1 of the 2 experimental diets containing $63 \%$ forage (low- or high-DCAD timothy) and 37\% concentrate (Table 2) at $30 \mathrm{~d}$ before the expected calving date. Diets were formulated to meet or exceed the nutrient requirements for cows in the close-up period (NRC, 2001). Cows were component fed timothy hay and concentrate at the same time, and equal portions of the diets were fed twice daily at 0900 and $1700 \mathrm{~h}$. Cows were housed in tie-stalls bedded with wood shavings and had free access to water. Following parturition, cows were fed a typical lactation diet formulated to contain adequate metabolizable protein and energy for a cow producing $35 \mathrm{~kg} / \mathrm{d}$ of $3.5 \%$ FCM.

\section{Data and Sample Collection}

The amount of feed offered and refused was recorded daily and adjusted to minimize refusals without re- stricting intake (5\% refusal). Forage samples were collected twice weekly and a concentrate sample was collected once weekly. Samples were oven-dried at $55^{\circ} \mathrm{C}$ for $48 \mathrm{~h}$ for determination of DM concentration. Dried feed samples were composited by month and analyzed by Cumberland Valley Analytical Service (Hagerstown, $\mathrm{MD})$. The nitrogen concentration was determined by flash combustion (Leco FP-528 Nitrogen Combustion Analyzer, Leco, St. Joseph, MI; AOAC, 2000; method 990.03) and was multiplied by 6.25 for calculation of $\mathrm{CP}$. The ADF concentration was determined according to AOAC (2000; method 973.18). The NDF concentration was determined according to the procedure of Goering and Van Soest (1970) using $\alpha$-amylase and sodium sulfite. The ash concentration was determined by subjecting samples to $535^{\circ} \mathrm{C}$ according to the AOAC (2000; method 942.05). The Ca, P, Mg, K, Na, Fe, Mn, Zn, and $\mathrm{Cu}$ concentrations were determined according to AOAC (2000; method 985.01). Samples were digested in nitric acid and analyzed using an optical emission spectrometer (Perkin Elmer 3300 XL ICP, Perkin Elmer, Shelton, CT). The S concentration was determined using Leco S-144DR Sulfur Combustion Analyzer (Leco). Samples were extracted with $1 \%$ nitric acid and determined for chloride ion by potentiometric measurement on a Corning 925 Chloride Analyzer (Ciba Corning Diagnostics, Medfield, MA). The DCAD ( $\mathrm{mEq} / 100 \mathrm{~g}$ of DM) was calculated as $\left(\mathrm{Na}^{+}+\mathrm{K}^{+}\right)-\left(\mathrm{Cl}^{-}+\mathrm{S}^{2-}\right)$ (Ender et al., 1971). The DMI was calculated as the difference between the amount of DM offered and the amount of DM refused. Orts were assumed to have the same DM concentration as the original feed offered. Data for prepartum DMI were summarized as weekly means.

Body weight and BCS were determined at the start of the study for each cow. An initial spot sample of urine was collected on the enrollment day and thereafter urine samples were collected twice weekly at $1100 \mathrm{~h}$ via manual stimulation or voluntary urination. Frequent sample collection was designed to obtain samples collected on $d-21,-14$, and -7 relative to parturition. Urinary $\mathrm{pH}$ was determined immediately using a portable $\mathrm{pH}$ meter (Accumet AP61, Fisher Scientific, Pittsburgh, PA). The $\mathrm{pH}$ meter was calibrated daily using standard buffers 4 and 7 .

Blood was collected on the enrollment day and thereafter twice weekly (Tuesday and Friday) corresponding to urine collection. Cows nearing parturition were observed hourly to collect blood samples immediately following parturition $(0 \mathrm{~h})$, and at 4, 8, 12, 16, 20, 24, 48, and $72 \mathrm{~h}$ following parturition. Blood from coccygeal vessels was drawn into 2 vacutainer tubes; one containing Li heparin (Fisher Scientific Co., Nepean, Ontario, Canada) and the other containing $\mathrm{Na}$ heparin (Fisher Scientific Co.). Whole blood in tubes containing 
Li heparin was immediately analyzed for $\mathrm{pH}$ and concentrations of $\mathrm{Na}, \mathrm{K}$, ionized $\mathrm{Ca}(\mathbf{i C a})$, and bicarbonate using an auto analyzer (GEM Premier 3000, Instrumentation Laboratory Ltd., Richmond Hill, Ontario, Canada). The blood in $\mathrm{Na}$ heparin tubes was immediately placed on ice and centrifuged within $30 \mathrm{~min}$ at $3,000 \times g$ and $4^{\circ} \mathrm{C}$ for $20 \mathrm{~min}$. Following centrifugation, the plasma was harvested and stored at $-20^{\circ} \mathrm{C}$. Plasma samples collected on the enrollment day, and at h 0,8 , 16,24 , and 72 following parturition were analyzed for PTH and 1,25- $(\mathrm{OH})_{2} \mathrm{D}$ concentrations by the Diagnostic Centre for Population Animal Health (Lansing, MI). The 1,25- $(\mathrm{OH})_{2} \mathrm{D}$ concentration in plasma samples were analyzed using a DiaSorin $1,25-(\mathrm{OH})_{2}$ D RIA Kit (DiaSorin, Stillwater, MN). Briefly, $1,25-(\mathrm{OH})_{2} \mathrm{D}$ was extracted and purified from plasma using $\mathrm{C} 18 \mathrm{OH}$ and "Extra Clean" cartridges (DiaSorin). Following extraction, the sample was assayed using a polyclonal antibody specific for $1,25-(\mathrm{OH})_{2} \mathrm{D}_{2}$ and $1,25-(\mathrm{OH})_{2} \mathrm{D}_{3}$, which avoids cross contamination with other vitamin $\mathrm{D}$ metabolites. The sample, antibody, and tracer were incubated for $2 \mathrm{~h}$ at $20^{\circ} \mathrm{C}$ followed by incubation with a second antibody to form a precipitating complex. After centrifugation and decantation, the bound fraction remaining in the pellet was counted in a gamma counter. Values were calculated directly from a standard curve of known concentrations. Intact PTH was measured using a 2-site immunoradiometric assay (Diagnostic Systems Laboratory, Webster, TX) that has been previously validated (Diagnostic Center for Population and Animal Health, Lansing, MI).

\section{Statistical Analysis}

Statistical analysis was conducted independently for prepartum and postpartum data. Preliminary statistical analysis determined that parity differences were not detectable between cows entering their third or greater lactation. Thus, for statistical analysis, cows were classed under 2 categories; 1 ) cows entering their second lactation, and 2) cows entering their third or greater lactation. The parity classification was used to group cows with similar susceptibility to hypocalcemia. Furthermore, data were analyzed to determine if initial values for $\mathrm{DMI}$, urine $\mathrm{pH}$, blood $\mathrm{pH}$, blood iCa, plasma $1,25-(\mathrm{OH})_{2} \mathrm{D}$, and plasma PTH were different between treatments. Statistical analysis revealed that initial treatment means for the previously mentioned variables were not different and therefore covariates were not used in subsequent analyses.

All data were analyzed using the PROC MIXED procedure of SAS (version 9.1.3; SAS Institute Inc., Cary, $\mathrm{NC}$ ) accounting for repeated measures with the random effect of cow nested in the parity class and the fixed effects of treatment and parity class. The prepartum repeated measures were week and day relative to parturition for DMI and blood parameters, respectively, and the postpartum repeated measure was hour relative to parturition. Various covariance error structures were tested for each dependent variable and the one that yielded the lowest Akaike's and Bayesian information criterion values was used. All data were analyzed for the main effects of treatment, parity class, time, and their interactions.

Postpartum data were also analyzed using the PROC MIXED procedure of SAS (version 9.1.3, SAS Institute Inc.) with hour relative to parturition as a regression variable to further characterize the response to timothy hay differing in DCAD. Linear effects for treatment, hour, parity, and their interactions and quadratic effects for hour, and the quadratic interactions between hour $\times$ treatment, hour $\times$ parity class, and hour $\times$ treatment $\times$ parity class were tested.

The change in blood iCa concentration following parturition was evaluated by comparing the nadir concentration to the prepartum baseline concentration. For this calculation, the nadir value observed postpartum was used and the baseline value was calculated by averaging the blood iCa concentrations for $\mathrm{d}-21,-14$, and -7 . Days $-21,-14$, and -7 relative to parturition were used for the baseline calculation because they did not differ over time. These data were analyzed using the PROC MIXED procedure of SAS (version 9.1.3; SAS Institute Inc.) with the fixed effects of treatment and parity class and the random effect of cow nested in parity class. Data were analyzed for the main effects of treatment, parity class, and the interaction between treatment and parity class.

For all statistical analyses mentioned above, differences were considered significant when $P<0.05$ and trends are discussed when $P<0.10$.

\section{RESULTS}

\section{Low- and High-DCAD Timothy Hay}

Timothy hay fertilized with $\mathrm{CaCl}_{2}$ had a greater $\mathrm{K}$ concentration (nearly 16\%) than timothy hay not fertilized with $\mathrm{CaCl}_{2}$ (Table 1), but this slightly greater $\mathrm{K}$ concentration was offset by a much greater $\mathrm{Cl}$ concentration (86\% increase). Thus, the marginal increase in $\mathrm{K}$ concentration and the large increase in $\mathrm{Cl}$ concentration for timothy hay fertilized with $\mathrm{CaCl}_{2}$ resulted in a lower DCAD than timothy hay not fertilized with $\mathrm{CaCl}_{2}$ (1.2 vs. $21.6 \mathrm{mEq} / 100 \mathrm{~g}$ of $\mathrm{DM})$.

\section{Prepartum}

The actual days for prepartum blood and urine collection were (mean $\pm \mathrm{SD})-29.1 \pm 0.7,-20.5 \pm 0.2,-13.7$ 
Table 3. The BW, BCS, DMI, prepartum urine $\mathrm{pH}$, blood $\mathrm{pH}$, blood bicarbonate, and blood ionized calcium concentrations of cows fed the low- or high-DCAD timothy diet during the 30-d prepartum period

\begin{tabular}{|c|c|c|c|c|c|c|}
\hline \multirow[b]{2}{*}{ Item } & \multicolumn{2}{|c|}{ Treatment } & \multirow[b]{2}{*}{ SEM } & \multicolumn{3}{|c|}{$P$-value } \\
\hline & Low DCAD & High DCAD & & Treatment & Day & Parity class $^{1}$ \\
\hline $\mathrm{BW}, \mathrm{kg}^{2}$ & 740 & 707 & 21.8 & 0.28 & - & 0.45 \\
\hline $\mathrm{BCS}^{2}$ & 3.32 & 3.22 & 0.08 & 0.39 & - & 0.54 \\
\hline DMI, kg/d & 11.0 & 10.2 & 0.6 & 0.37 & $<0.01$ & 0.15 \\
\hline Urine $\mathrm{pH}^{3}$ & 7.77 & 8.25 & 0.06 & $<0.01$ & $<0.01$ & 0.46 \\
\hline Blood $\mathrm{pH}^{4}$ & 7.44 & 7.44 & 0.01 & 0.34 & 0.11 & 0.90 \\
\hline Blood bicarbonate, $\mathrm{m} M$ & 27.2 & 29.4 & 0.42 & $<0.01$ & 0.94 & 0.86 \\
\hline Blood ionized $\mathrm{Ca},{ }^{4} \mathrm{~m} M$ & 1.22 & 1.19 & 0.01 & 0.01 & $<0.01$ & 0.13 \\
\hline
\end{tabular}

\footnotetext{
${ }^{1}$ Cows entering their second lactation and their third or greater lactation were assigned to different parity classes.

${ }^{2}$ Body weight and BCS measured on the study enrollment day ( $-29 \pm 0.7$ relative to parturition). Body condition score was measured using a 5-point scale according to Wildman et al. (1982).

${ }^{3}$ Significant treatment $\times$ day interaction $(P<0.01)$.

${ }^{4}$ Significant day $\times$ parity class interaction $(P<0.05)$.
}

\pm 0.2 , and $-6.6 \pm 0.2 \mathrm{~d}$ relative to parturition. These collection days were close to the targeted days of -30 , $-21,-14$, and $-7 \mathrm{~d}$ relative to parturition, respectively.

The prepartum BW and BCS of cows fed the lowDCAD and high-DCAD treatments were not different and averaged $724 \mathrm{~kg}$ and $3.27 \mathrm{BCS}$ respectively (Table 3). Prepartum DMI was not affected by dietary treatment ( $P=0.37$; Table 3$)$ but it was affected by week relative to parturition $(P<0.01$; Figure 1$)$. Average DMI across treatments was $11.3,11.2$, and $9.2 \mathrm{~kg} / \mathrm{d}$ for wk $-3,-2$, and -1 relative to parturition, respectively; for both treatment groups of cows, DMI decreased by an average of $18 \%$ during the week before calving. Mean urine $\mathrm{pH}$ over the entire prepartum period was nearly $0.5 \mathrm{pH}$ units lower for cows fed low-DCAD timothy than cows fed high-DCAD timothy hay (Table 3). Furthermore, there was a treatment $x$ day interaction for urine $\mathrm{pH}$. Feeding low-DCAD timothy hay decreased urinary $\mathrm{pH}$ from $8.16 \pm 0.08$ on $\mathrm{d}-30$ to $7.50 \pm 0.08$ on $\mathrm{d}-7$

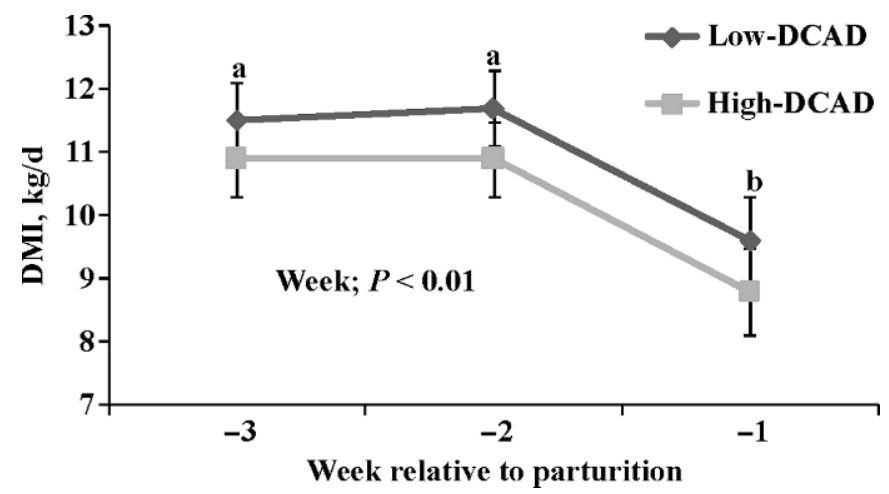

Figure 1. The DMI of cows fed the low- or high-DCAD timothy diet for $30 \mathrm{~d}$ before the expected calving date. Weeks with uncommon letters are significantly different $(P<0.05)$. relative to parturition; however, feeding high-DCAD timothy hay had no effect on urinary $\mathrm{pH}$ with values of $8.27 \pm 0.08$ and $8.19 \pm 0.09$ on $d-30$ and -7 , respectively (Figure 2). Blood $\mathrm{pH}$ was not affected by treatment, day relative to parturition, or parity class, although an interaction between parity class and day relative to parturition was detected $(P<0.05)$. The interaction was a result of cows entering their third or greater lactation having a decrease in blood $\mathrm{pH}$ from trial initiation to $\mathrm{d}-7$, whereas cows entering their second lactation had no change in their blood $\mathrm{pH}$ values during the same time (data not shown). Blood bicarbonate concentration was 7\% lower for cows fed low-DCAD timothy hay than for cows fed high-DCAD timothy hay (Table 3). Furthermore, there was a tendency $(P=0.07)$ for a treatment $x$ day interaction for blood bicarbonate concentration; the low-DCAD treatment tended to reduce blood bicarbonate concentrations as the calving date approached,

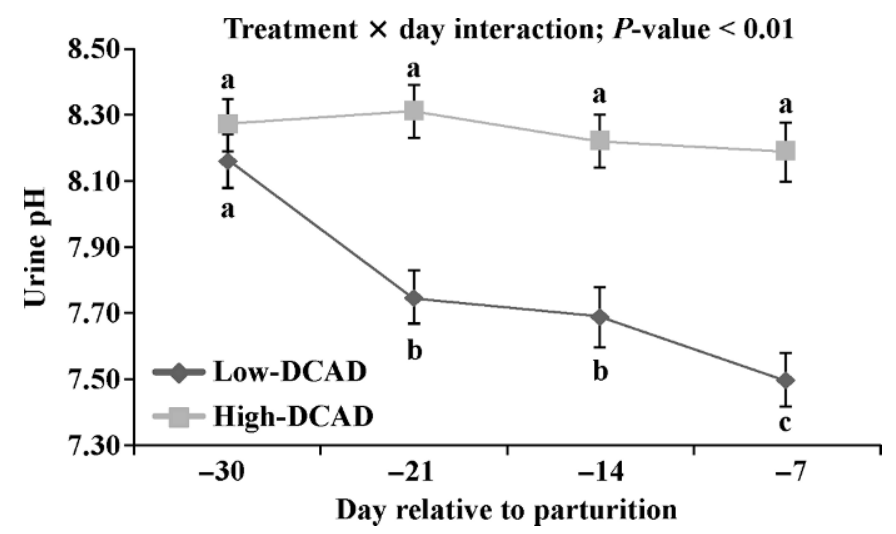

Figure 2. The treatment $x$ day interaction for prepartum urine $\mathrm{pH}$ in cows fed the low- or the high-DCAD timothy diet for $30 \mathrm{~d}$ before their expected calving date. All data points with uncommon letters are significantly different $(P<0.05)$. 
Table 4. Percentage of cows experiencing disorders during the first $72 \mathrm{~h}$ postpartum after they were fed the low- or high-DCAD timothy diet for $30 \mathrm{~d}$ before their expected calving date

\begin{tabular}{lcc}
\hline & \multicolumn{2}{c}{ Treatment } \\
\cline { 2 - 3 } Item & Low & High \\
\hline Number of cows per treatment & 20 & DCAD \\
Retained placenta, $\%$ & 5.0 & 21 \\
Displaced abomasums, $\%$ & 5.0 & 19.0 \\
Subclinical hypocalcemia ${ }^{1} \%$ & 35.0 & 9.5 \\
\hline
\end{tabular}

${ }^{1}$ Ionized calcium concentration in blood $<1 \mathrm{~m} M$.

whereas the high-DCAD treatment did not affect blood bicarbonate concentrations (data not shown). The prepartum concentration of blood iCa was greater for cows fed low-DCAD timothy diet when compared with cows fed high-DCAD timothy diet (1.22 vs. $1.19 \mathrm{~m} M$, respectively; $P=0.01$ ). Blood iCa concentration increased slightly from the initial concentration of $1.18 \mathrm{~m} M$ on d -30 to $1.21 \mathrm{~m} M$ for $\mathrm{d}-21$ and reached a plateau thereafter (week; $P<0.01$, data not shown). An interaction between parity class and day relative to parturition was detected for blood iCa concentration where cows entering their third or greater lactation initially had lower blood iCa concentration than cows entering their second lactation (1.16 vs. $1.20 \mathrm{mM}$, respectively) but had similar blood iCa concentrations on $\mathrm{d}-21,-14$, and -7 relative to parturition (data not shown).

\section{Postpartum}

Metabolic Disorders. The occurrence of metabolic disorders is summarized in Table 4, but statistical analysis was not conducted. Although no visual signs of clinical hypocalcemia were observed, $35 \%$ of the cows fed the low-DCAD diet and $67 \%$ of the cows fed the high-DCAD diet had blood iCa concentrations below 1 $\mathrm{m} M$, a threshold used to define subclinical hypocalcemia (Joyce et al., 1997). There was also a numerically greater percentage of retained placenta and displaced abomasum in cows fed the high-DCAD timothy diet.

Treatment Effects. Prepartum treatment did not affect postpartum blood $\mathrm{pH}(P>0.10$; Table 5). A treatment $\times$ postpartum hour interaction was detected for blood pH ( $P=0.02$; data not shown). Cows fed the lowDCAD timothy diet had numerically lower blood $\mathrm{pH}$ at the time of calving $(0 \mathrm{~h})$, numerically greater blood $\mathrm{pH}$ at $12 \mathrm{~h}$ postpartum, but similar blood $\mathrm{pH} 72 \mathrm{~h}$ postpartum when compared with cows fed the high-DCAD timothy diet. The overall effect of this interaction was a reduction in the difference for blood $\mathrm{pH}$ over time between the low-DCAD and high-DCAD treatments. Feeding low-DCAD timothy diet tended to increase $(P=$
0.10) the concentration of iCa in blood postpartum when compared with high-DCAD timothy diet (1.09 vs. 1.06 $\mathrm{m} M)$. Because there was no difference in prepartum blood iCa concentrations for $\mathrm{d}-21,-14$, and -7 , values were averaged for each cow individually to determine the baseline concentration. The baseline concentration was then compared with the nadir value observed postpartum for each cow. The nadir value for blood iCa concentration was nearly $6 \%$ greater $(P=0.05)$ for cows fed the low-DCAD diet compared with the high-DCAD timothy diet. However, the nadir value for blood iCa concentration as a proportion of the baseline was not different between dietary treatments, and averaged $81.5 \%$. Plasma concentrations of $1,25-(\mathrm{OH})_{2} \mathrm{D}$ and PTH were not affected by dietary treatments.

Hour Effects. We further examined the response of postpartum blood parameters over time (Table 6). There was a quadratic relationship $(P<0.01)$ for blood $\mathrm{pH}$ over time with $\mathrm{pH}$ increasing from the time of calving until $16 \mathrm{~h}$ after calving but reaching a plateau thereafter. A significant quadratic hour $\times$ treatment interaction $(P=0.04$; data not shown) was detected for blood bicarbonate concentration. This interaction was a result of cows on the low-DCAD treatment having lower blood bicarbonate concentrations than cows on the high-DCAD treatment at h $0(27.7$ vs. $30.6 \mathrm{mM})$ and 4 (28.8 and $31.5 \mathrm{mM}$ ) after parturition respectively. But similar concentrations of blood bicarbonate were observed thereafter, averaging 31.5 and $32.8 \mathrm{mM}$ for the low-DCAD and high-DCAD treatments, respectively. Blood iCa concentration responded linearly $(P<0.01)$; however, there was a quadratic hour $\times$ parity class interaction $(P<0.01$; data not shown $)$ and a quadratic hour $\times$ treatment interaction $(P<0.01$; Figure 3$)$. Cows entering their third or greater parity had lower blood $\mathrm{iCa}$ at 0 and $4 \mathrm{~h}$ following parturition but greater $\mathrm{iCa}$ after $48 \mathrm{~h}$ (data not shown). The quadratic hour $\times$ treatment interaction was a result of cows fed the low-DCAD timothy diet having greater blood iCa at 0 and $8 \mathrm{~h}$ after parturition and numerically greater iCa for the first 20 $\mathrm{h}$ following parturition than cows fed the high-DCAD timothy diet. However, iCa concentration was similar between treatments at h 24, 48, and 72 (Figure 3). A linear effect of postpartum time was detected for plasma PTH (Table 6) with PTH concentrations remaining high for more than $24 \mathrm{~h}$ following parturition, but it decreased by $15 \%$ at $\mathrm{h} 72$. Plasma $1,25-(\mathrm{OH})_{2} \mathrm{D}$ was lowest immediately following parturition $(0 \mathrm{~h})$ and increased 8 and $16 \mathrm{~h}$ after calving with no further increase thereafter (quadratic; $P<0.01$, Table 6 ).

\section{DISCUSSION}

\section{Periparturient Ca Homeostasis}

This is the first study known to the authors that has investigated the effect of forages differing in DCAD 
Table 5. Postpartum blood $\mathrm{pH}$, blood concentrations of bicarbonate and ionized $\mathrm{Ca}$ (iCa), and plasma concentrations of parathyroid hormone (PTH) and 1,25 dihydroxyvitamin $\mathrm{D}\left[1,25-(\mathrm{OH})_{2} \mathrm{D}\right]$ in cows fed the low- or high-DCAD timothy diet for $30 \mathrm{~d}$ before their expected calving date

\begin{tabular}{|c|c|c|c|c|c|c|}
\hline \multirow[b]{2}{*}{ Variable } & \multicolumn{2}{|c|}{ Treatment } & \multirow[b]{2}{*}{ SEM } & \multicolumn{3}{|c|}{$P$-value } \\
\hline & Low DCAD & High DCAD & & Treatment & Hour & Parity class \\
\hline \multicolumn{7}{|l|}{ Blood } \\
\hline $\mathrm{pH}^{1}$ & 7.45 & 7.46 & 0.01 & 0.15 & $<0.01$ & 0.87 \\
\hline Bicarbonate, $\mathrm{m} M$ & 30.8 & 32.4 & 0.78 & 0.14 & $<0.01$ & 0.82 \\
\hline $\mathrm{iCa},{ }^{2} \mathrm{~m} M$ & 1.09 & 1.06 & 0.01 & 0.10 & $<0.01$ & 0.68 \\
\hline Baseline $\mathrm{iCa},{ }^{3} \mathrm{~m} M$ & 1.23 & 1.20 & 0.01 & 0.01 & $\mathrm{NA}^{5}$ & 0.54 \\
\hline Nadir iCa,${ }^{4} \mathrm{~m} M$ & 1.02 & 0.96 & 0.02 & 0.05 & NA & 0.44 \\
\hline Nadir iCa, ${ }^{4} \%$ of baseline & 82.9 & 80.2 & 1.47 & 0.20 & NA & 0.52 \\
\hline \multicolumn{7}{|l|}{ Plasma } \\
\hline PTH, pM & 5.05 & 6.68 & 1.12 & 0.27 & $<0.01$ & 0.76 \\
\hline $1,25(\mathrm{OH})_{2} \mathrm{D}, \mathrm{p} M$ & 267 & 320 & 27.1 & 0.13 & $<0.01$ & 0.75 \\
\hline
\end{tabular}

${ }^{1}$ Significant treatment $\times$ hour interaction $(P=0.02)$.

${ }^{2}$ Significant hour $\times$ parity class interaction $(P<0.01)$.

${ }^{3}$ The mean blood iCa concentration for $\mathrm{d}-21,-14$, and -7 relative to parturition calculated for each cow.

${ }^{4}$ The lowest blood iCa concentration observed for each cow postpartum.

${ }^{5} \mathrm{NA}=$ not available.

on calcium homeostasis in transition dairy cows. To produce timothy hays with contrasting DCAD, we fertilized the hay with 0 or $224 \mathrm{~kg}$ of $\mathrm{CaCl}_{2} / \mathrm{ha}$. Our results confirm those of previous studies that demonstrated that $\mathrm{Cl}$ fertilization decreases the DCAD of timothy hay (Oba et al., 2007; Pelletier et al., 2007, 2008) or alfalfa (Goff et al., 2007).

In the current study, feeding the low-DCAD timothy diet reduced the metabolic alkalosis prepartum as indicated by decreased urinary $\mathrm{pH}$ and blood bicarbonate concentration when compared with feeding the highDCAD timothy diet. Previous studies also reported that low or negative DCAD diets induce metabolic acidosis as indicated by reduced urine $\mathrm{pH}$ and blood bicarbonate concentration (Goff and Horst, 1998; Moore et al., 2000; Roche et al., 2003). However, the degree of metabolic acidosis in the previously mentioned studies was greater than in the current study. Metabolic acidosis increase the tissue responsiveness to $\mathrm{PTH}$, increasing the synthesis of $1,25-(\mathrm{OH})_{2} \mathrm{D}$, and thus improving the ability to increase plasma Ca through mobilization, resorption, and absorption (Horst et al., 1997). Correspondingly, we observed a greater concentration of iCa prepartum for cows fed the low-DCAD timothy diet when compared with cows fed the high-DCAD timothy diet. Greater blood iCa concentration has been consistently reported when cows are fed diets containing a low or negative DCAD (Tucker et al., 1992; Moore et al.,

Table 6. The effect of time after parturition on blood $\mathrm{pH}$, bicarbonate, ionized $\mathrm{Ca}$ (iCa), parathyroid hormone (PTH), and 1,25 dihydroxyvitamin $\mathrm{D}\left[1,25-(\mathrm{OH})_{2} \mathrm{D}\right]$ when cows were fed the low- or high-DCAD timothy diet for $30 \mathrm{~d}$ before their expected calving date (average of the 2 dietary treatment groups)

\begin{tabular}{|c|c|c|c|c|c|c|c|c|c|c|c|}
\hline Variable & \multicolumn{9}{|c|}{ Hour relative to parturition } & \multicolumn{2}{|c|}{$P$-value } \\
\hline $\begin{array}{l}\text { Blood pH } \\
\text { SEM }\end{array}$ & $\begin{array}{l}7.42^{\mathrm{e}} \\
0.01\end{array}$ & $\begin{array}{l}7.43^{\mathrm{de}} \\
0.01\end{array}$ & $\begin{array}{l}7.44^{\mathrm{cd}} \\
0.01\end{array}$ & $\begin{array}{l}7.46^{\mathrm{bc}} \\
0.01\end{array}$ & $\begin{array}{l}7.46^{\mathrm{bc}} \\
0.01\end{array}$ & $\begin{array}{l}7.47^{\mathrm{ab}} \\
0.01\end{array}$ & $\begin{array}{l}7.47^{\mathrm{ab}} \\
0.01\end{array}$ & $\begin{array}{l}7.47^{\mathrm{ab}} \\
0.01\end{array}$ & $\begin{array}{l}7.48^{\mathrm{a}} \\
0.01\end{array}$ & $<0.01$ & $<0.01$ \\
\hline $\begin{array}{l}\text { Bicarbonate, }{ }^{1} \mathrm{~m} M \\
\text { SEM }\end{array}$ & $\begin{array}{r}29.2^{\mathrm{e}} \\
0.65\end{array}$ & $\begin{array}{c}30.2^{\mathrm{de}} \\
0.65\end{array}$ & $\begin{array}{r}30.5^{\mathrm{d}} \\
0.65\end{array}$ & $\begin{array}{c}31.2^{\text {cd }} \\
0.65\end{array}$ & $\begin{array}{c}32.1^{\mathrm{bc}} \\
0.65\end{array}$ & $\begin{array}{c}32.6^{\mathrm{ab}} \\
0.65\end{array}$ & $\begin{array}{c}32.7^{\mathrm{ab}} \\
0.65\end{array}$ & $\begin{array}{r}33.5^{\mathrm{a}} \\
0.65\end{array}$ & $\begin{array}{r}32.4^{\mathrm{b}} \\
0.65\end{array}$ & $<0.01$ & $<0.01$ \\
\hline $\begin{array}{l}\mathrm{iCa},{ }^{2} \mathrm{~m} M \\
\mathrm{SEM}\end{array}$ & $\begin{array}{l}1.06^{\text {cd }} \\
0.01\end{array}$ & $\begin{array}{l}1.05^{\mathrm{d}} \\
0.01\end{array}$ & $\begin{array}{l}1.07^{\text {bcd }} \\
0.01\end{array}$ & $\begin{array}{l}1.07^{\mathrm{bc}} \\
0.01\end{array}$ & $\begin{array}{l}1.06^{\mathrm{d}} \\
0.01\end{array}$ & $\begin{array}{l}1.05^{\mathrm{d}} \\
0.01\end{array}$ & $\begin{array}{l}1.06^{\mathrm{cd}} \\
0.01\end{array}$ & $\begin{array}{l}1.11^{\mathrm{ab}} \\
0.01\end{array}$ & $\begin{array}{l}1.12^{\mathrm{a}} \\
0.01\end{array}$ & $<0.01$ & 0.90 \\
\hline $\begin{array}{l}1,25-(\mathrm{OH})_{2} \mathrm{D}, \mathrm{p} M \\
\text { SEM }\end{array}$ & $\begin{array}{c}235^{\mathrm{c}} \\
18.5\end{array}$ & - & $\begin{array}{c}279^{b} \\
18.6\end{array}$ & - & $\begin{array}{l}321^{\mathrm{a}} \\
20.0\end{array}$ & - & $\begin{array}{c}338^{\mathrm{a}} \\
21.2\end{array}$ & - & $\begin{array}{r}293^{\mathrm{ab}} \\
18.6\end{array}$ & 0.32 & $<0.01$ \\
\hline
\end{tabular}

${ }^{\mathrm{a}-\mathrm{d}}$ Means within a row with uncommon superscripts differ significantly $(P<0.05)$.

${ }^{1}$ Significant quadratic hour $\times$ treatment interaction $(P=0.04)$.

${ }^{2}$ Significant quadratic hour $\times$ parity class interaction $(P<0.01)$. 


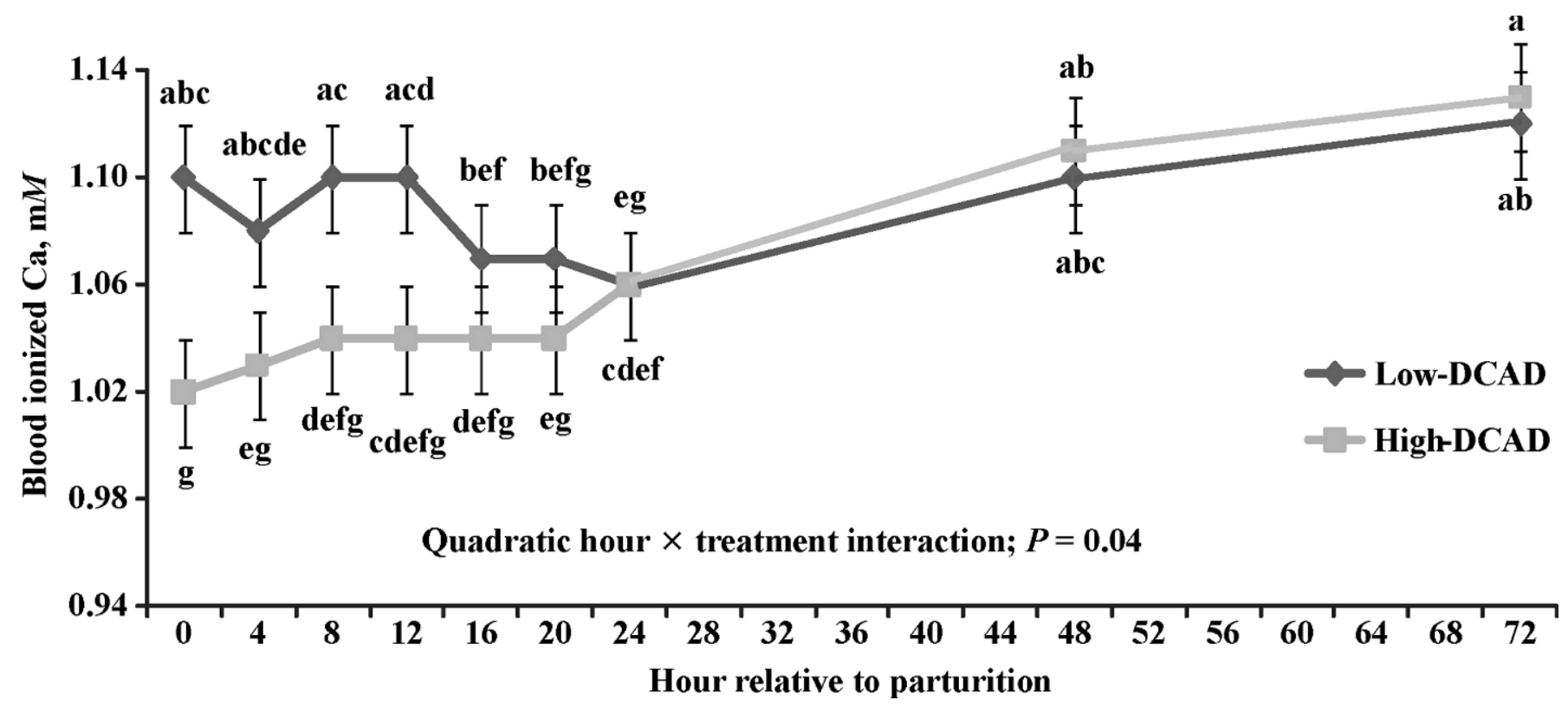

Figure 3. The quadratic hour $\times$ treatment interaction for postpartum blood ionized calcium (iCa) concentration in cows fed the low- or high-DCAD timothy diet for $30 \mathrm{~d}$ before the expected calving date. All data points with uncommon letters are significantly different $(P<0.05)$.

2000). In the current study, the blood iCa concentration following parturition also tended to be greater for cows fed the low-DCAD timothy hay than cows fed the highDCAD timothy hay as indicated by a quadratic hour $x$ treatment interaction. These data indicate improved iCa homeostasis immediately after parturition for cows fed low-DCAD over cows fed high-DCAD timothy diets.

Recently, there has been interest in the potential of using diets with a low but positive DCAD to improve $\mathrm{Ca}$ homeostasis around parturition. Kurosaki et al. (2007) reported that multiparous cows fed a diet containing $1.2 \mathrm{mEq} / 100 \mathrm{~g}$ of $\mathrm{DM}$ had lower urinary $\mathrm{pH}$ prepartum, greater serum Ca during the first $3 \mathrm{~d}$ following parturition, and required less treatment for hypocalcemia compared with multiparous cows fed diets containing 14.6 or $15.3 \mathrm{mEq} / 100 \mathrm{~g}$ of DM. As such, multiparous cows fed the $1.2 \mathrm{mEq} / 100 \mathrm{~g}$ of DM diet had $50 \%$ less hypocalcemia (serum $\mathrm{Ca}<5 \mathrm{mg} / \mathrm{dL}$ ) than multiparous cows fed high-DCAD diets. Similarly, in the current study, we observed decreased urinary $\mathrm{pH}$ and blood bicarbonate concentration prepartum, improved iCa concentration postpartum, and a $48 \%$ reduction in the prevalence of subclinical hypocalcemia for cows fed the low-DCAD (1.6 mEq/100 $\mathrm{g}$ of $\mathrm{DM})$ compared with cows fed the high-DCAD (14.5 mEq/100 g of DM) diet.

Although we saw a drastic reduction in the prevalence of subclinical hypocalcemia, $35 \%$ of the cows fed the low-DCAD timothy diet were still diagnosed with this disorder. Reported prevalence rates for hypocalcemia in cows fed low but positive DCAD diets have ranged from $11 \%$ for cows fed a diet with a DCAD of 1.2 (Kurosaki et al., 2007; serum $\mathrm{Ca}<5 \mathrm{mg} / \mathrm{dL}$ ) to $50 \%$ for cows fed a diet with a DCAD value of $0 \mathrm{mEq} / 100$ $\mathrm{g}$ of DM (Moore et al., 2000; plasma $\mathrm{Ca}<4 \mathrm{mg} / \mathrm{dL}$ ). Furthermore, Moore et al. (2000) reported improvements in Ca homeostasis as the DCAD value of the diet was reduced from +15 to 0 and from 0 to $-15 \mathrm{mEq} / 100$ $\mathrm{g}$ of DM. Although diets containing a low but positive DCAD may reduce the prevalence of hypocalcemia, the prevalence could be reduced to a greater extent by reducing the DCAD further. Further research is warranted to determine the optimal DCAD that accounts for both reducing the prevalence of hypocalcemia and minimizing depression in DMI.

Much attention has been directed toward the effects of PTH and 1,25- $(\mathrm{OH})_{2} \mathrm{D}$ on calcium homeostasis in dairy cows. In the current study, plasma concentrations of PTH and 1,25-(OH $)_{2} \mathrm{D}$ did not differ between the 2 dietary treatments. The plasma concentration of PTH remained high for $24 \mathrm{~h}$ after calving but decreased by $\mathrm{h} 72$. Further, it took approximately $16 \mathrm{~h}$ before plasma $1,25-(\mathrm{OH})_{2} \mathrm{D}$ reached its peak concentration. The slow response for an increase in plasma $1,25-(\mathrm{OH})_{2} \mathrm{D}$ concentration may be due in part to PTH resistance (Martig and Mayer, 1973). Supporting the notion of PTH resistance, upon simple correlation analysis, there was no relationship between plasma PTH and 1,25- $(\mathrm{OH})_{2}$ D concentrations, nor between plasma PTH and iCa concentrations. Consistent with previous findings (Horst et al., 1997), we observed that plasma $1,25-(\mathrm{OH})_{2} \mathrm{D}$ 
increased when iCa concentration was low but decreased from h 24 to 72 corresponding to an increase in iCa concentration. This corresponded to a significant but weak negative correlation between plasma 1,25 $(\mathrm{OH})_{2} \mathrm{D}$ and blood iCa concentration $\left(\mathrm{r}^{2}=0.18, P<\right.$ $0.01)$. These results suggests that cows in the current study were responsive to circulating $1,25-(\mathrm{OH})_{2} \mathrm{D}$ in plasma but may have experienced tissue resistance to PTH.

In the current study, feeding a low-DCAD timothy diet increased the baseline blood iCa concentration and the nadir $\mathrm{iCa}$ concentration relative to the high-DCAD timothy diet. However, there was no difference between treatments for the extent of reduction in blood iCa concentration following parturition. We speculate that differences in tissue sensitivity to PTH between the prepartum and postpartum periods may explain why cows fed the low-DCAD timothy diet in the current study had greater prepartum blood iCa concentration but a similar decrease in postpartum blood iCa concentration. Martig and Mayer (1973) injected PTH intramuscularly before and after parturition and observed that PTH resistance was greater before parturition than following parturition. In our study, feeding a low-DCAD timothy diet decreased the prepartum blood bicarbonate concentration, an indicator of mild metabolic acidosis, but following parturition there was no difference in blood bicarbonate concentration between dietary treatments. Thus, carry-over effects of feeding the lowDCAD timothy diet on metabolic acidosis may have been minimal. The dietary treatment effect on prepartum blood iCa concentration observed in our study was in agreement with those reported by Kurosaki et al. (2007). Furthermore, in the study of Moore et al. (2000), blood samples were collected within $4 \mathrm{~h}$ of calving and they reported that the postpartum iCa concentration in blood decreased to a similar extent (83 and $82 \%$ of the prepartum $\mathrm{iCa}$ ) for cows fed diets with $\mathrm{DCAD}$ values of +15 and $0 \mathrm{mEq} / 100 \mathrm{~g}$ of DM. Based on results of the current and previous studies, the postpartum improvement in blood iCa concentration for diets having a low but positive DCAD may be a response of greater prepartum blood iCa concentration rather than a greater ability to prevent a reduction in postpartum iCa blood concentration, whereas diets with a negative $\mathrm{DCAD}$ value seem to reduce the extent of blood iCa postpartum depression in addition to increased prepartum iCa blood concentration (Moore et al., 2000; Kurosaki et al., 2007).

\section{DMI}

It is well documented that feeding close-up diets of a negative DCAD value improves Ca homeostasis around parturition (Oetzel, 1991; Horst et al., 1997; Lean et al., 2006), but a negative DCAD ration often decreases DMI especially if a great amount of anionic salts are used (Tucker et al., 1992; Joyce et al., 1997; Vagnoni and Oetzel, 1998). Charbonneau et al. (2006a) recently conducted a meta-analysis encompassing 22 studies and found a positive linear relationship between the DCAD and DMI. In the current study, we did not observe a reduction in $\mathrm{DMI}$ with the low-DCAD relative to the high-DCAD timothy diet. Although the low-DCAD timothy hay provided a lower DCAD than the highDCAD timothy hay, the diet based on the low-DCAD timothy hay still provided a positive DCAD (cations > anions). As a result, the metabolic acidosis in the current study for cows fed the low-DCAD timothy diet was not as severe as in previous studies using anionic supplements (Tucker et al., 1992; Goff and Horst, 1998; Vagnoni and Oetzel, 1998). It is therefore possible that the low-DCAD timothy diet did not induce metabolic acidosis severe enough to reduce DMI.

Alternatively, it is possible that the form of the DCAD supplement may influence the depression in DMI. Charbonneau et al. (2008) compared 3 diets consisting of 1) a low-DCAD diet $(-2.4 \mathrm{mEq} / 100 \mathrm{~g}$ of $\mathrm{DM})$ using only low-DCAD timothy hay, 2) a low-DCAD $\operatorname{diet}(-1.9$ $\mathrm{mEq} / 100 \mathrm{~g}$ of DM) made with a combination of low- and high-DCAD timothy hay and additional $\mathrm{HCl}$, and 3) a high-DCAD diet ( $29.6 \mathrm{mEq} / 100 \mathrm{~g}$ of DM) made with the same combination of low- and high-DCAD timothy hay. These diets were fed to nonpregnant and nonlactating cows, and cows fed the low-DCAD diet had similar DMI to those fed the high-DCAD timothy diet. Cows fed the diet supplemented with $\mathrm{HCl}$, however, tended $(P=0.08)$ to have lower DMI $(9.8 \mathrm{~kg} / \mathrm{d})$ than cows fed the lowDCAD timothy hay diet $(11.5 \mathrm{~kg} / \mathrm{d})$ even though the DCAD of the low-DCAD timothy diet was slightly lower than that of the $\mathrm{HCl}$-supplemented diet. However, not all studies using $\mathrm{HCl}$ have resulted in reduced DMI (Goff and Horst, 1998). The results of the current study and those of Charbonneau et al. (2008) suggest that the form of DCAD supplement, rather than the DCAD value itself, may have an impact on DMI. However, in another study, feeding timothy silage with a low DCAD value $(-2.1 \mathrm{mEq} / 100 \mathrm{~g}$ of $\mathrm{DM})$ tended to reduce DMI when compared with the control treatment $(23 \mathrm{mEq} /$ $100 \mathrm{~g}$ of DM; Charbonneau et al., 2006b). More data are needed to elucidate the relationship between decreased DMI and the severity of the metabolic acidosis while using different anionic supplements.

\section{CONCLUSIONS}

Feeding a diet based on a low-DCAD timothy hay during the prepartum period had no effect on DMI and induced a mild but compensated metabolic acidosis, 
improving the ability of cows to maintain calcium homeostasis around parturition compared with feeding a diet based on a high-DCAD timothy hay. These results indicate that feeding timothy hay with a low DCAD may be one strategy to reduce hypocalcemia in periparturient dairy cows.

\section{ACKNOWLEDGMENTS}

The authors thank the staff of the Dairy Research and Technology Centre farm staff for general animal husbandry and the staff of the University of Alberta Metabolic Unit for assistance with timothy hay delivery. Gratitude is extended to M. A. Bal, L. McKeown, C. Silveira, and S. Vishantha-Patabendi for technical assistance. Financial support from Zen-Raku-Ren (Japanese Federation of Dairy Cooperative Associations), Advancing Canadian Agriculture and Agri-Food program of Agriculture and Food Council, and Alberta Milk are gratefully acknowledged.

\section{REFERENCES}

AOAC. 2000. Official Methods of Analysis. 17th ed. Vol. 1. 2000. AOAC, Arlington, VA.

Block, E. 1984. Manipulating dietary anions and cations for prepartum dairy cows to reduce incidence of milk fever. J. Dairy Sci. 67:2939-2948.

Block, E. 1994. Manipulation of dietary cation-anion difference on nutritionally related production diseases, productivity, and metabolic responses of dairy cows. J. Dairy Sci. 77:1437-1450.

Charbonneau, E., P. Y. Chouinard, G. F. Tremblay, G. Allard, and D. Pellerin. 2008. Hay to reduce dietary cation-anion difference of dairy cows. J. Dairy Sci. 91:1585-1596.

Charbonneau, E., P. Y. Chouinard, G. F. Tremblay, A. Brégard, G. Allard, and D. Pellerin. 2006b. Silage to reduce dietary cationanion difference. J. Dairy Sci. 89(Suppl. 1):227. (Abstr.)

Charbonneau, E., D. Pellerin, and G. R. Oetzel. 2006a. Impact of lowering dietary cation-anion difference in nonlactating dairy cows: A meta-analysis. J. Dairy Sci. 89:537-548.

Ender, F., I. W. Dishington, and A. Helgebostad. 1971. Calcium balance studies in dairy cows under experimental induction and prevention of hypocalcaemic paresis puerperalis. Z. Tierphysiol. Tierer. 28:233-256.

Goering, H. K., and P. J. Van Soest. 1970. Forage Fiber Analysis. USDA Agricultural Research Service. Handbook number 379. US Dept. Agriculture. US Government Printing Office, Washington, DC.

Goff, J. P., E. C. Brummer, S. J. Henning, R. K. Doorenbos, and R. L. Horst. 2007. Effect of application of ammonium chloride and calcium chloride on alfalfa cation-anion content and yield. J. Dairy Sci. 90:5159-5164.
Goff, J. P., and R. L. Horst. 1998. Use of hydrochloric acid as a source of anions for prevention of milk fever. J. Dairy Sci. 81:2874-2880.

Goff, J. P., R. L. Horst, F. J. Mueller, J. K. Miller, G. A. Kiess, and H. H. Dowlen. 1991. Addition of chloride to a prepartal diet high in cations increases 1,25-dihydroxyvitamin D response to hypocalcemia preventing milk fever. J. Dairy Sci. 74:3863-3871.

Horst, R. L., J. P. Goff, T. A. Reinhardt, and D. R. Buxton. 1997. Strategies for preventing milk fever in dairy cattle. J. Dairy Sci. 80:1269-1280.

Joyce, P. W., W. K. Sanchez, and J. P. Goff. 1997. Effect of anionic salts in prepartum diets based on alfalfa. J. Dairy Sci. 80:2866-2875.

Kurosaki, N., O. Yamato, F. Mori, S. Imoto, and Y. Maede. 2007. Preventive effect of mildly altering dietary cation-anion difference on milk fever in dairy cows. J. Vet. Med. Sci. 69:185-192.

Lean, I. J., P. J. DeGaris, D. M. McNeil, and E. Block. 2006. Hypocalcaemia in dairy cows: Meta-analysis and dietary cation-anion difference theory revisited. J. Dairy Sci. 89:669-684.

Martig, J., and G. P. Mayer. 1973. Diminished hypercalcemic response to parathyroid extract in prepartum cows. J. Dairy Sci. 56:1042-1046.

Moore, S. J., M. J. VandeHaar, B. K. Sharma, T. E. Pilbeam, D. K. Beede, H. F. Bucholtz, J. S. Liesman, R. L. Horst, and J. P. Goff. 2000. Effects of altering dietary cation-anion difference on calcium and energy metabolism in peripartum cows. J. Dairy Sci. 83:2095-2104.

NRC. 2001. Nutrient Requirements of Dairy Cattle. 7th rev. ed. Natl. Acad. Press, Washington, DC.

Oba, M., R. Holm, R. McKenzie, and T. Dow. 2007. Fertilization using potassium chloride decreased the DCAD of timothy hay. J. Dairy Sci. 90(Suppl. 1):512. (Abstr.)

Oetzel, G. R. 1991. Meta-analysis of nutritional risk factors for milk fever in dairy cattle. J. Dairy Sci. 74:3900-3912.

Pelletier, S., G. Bélanger, G. F. Tremblay, P. Sequin, R. Drapeau, and G. Allard. 2007. Dietary cation-anion difference of timothy (Phleum pratense L.) as influenced by application of chloride and nitrogen fertilizer. Grass Forage Sci. 62:66-77.

Pelletier, S., G. F. Tremblay, G. Bélanger, M. H. Chantigny, P. Sequin, R. Drapeau, and G. Allard. 2008. Nutritive value of timothy fertilized with $\mathrm{Cl}$ or Cl-containing liquid swine manure. J. Dairy Sci. 91:713-721.

Roche, J. R., D. Dalley, P. Moate, C. Grainger, M. Rath, and F. O’Mara. 2003. A low dietary cation-anion difference precalving and calcium supplementation postcalving increase plasma calcium but not milk production in a pasture-based system. J. Dairy Sci. 86:2658-2666.

Tremblay, G. F., H. Brassard, G. Bélanger, P. Sequin, R. Drapeau, A. Brégard, R. Michaud, and G. Allard. 2006. Dietary cationanion difference of five cool-season grasses. Agron. J. 98:339-348.

Tucker, W. B., J. F. Hogue, G. D. Adams, M. Aslam, I. S. Shin, and G. Morgan. 1992. Influence of dietary cation-anion balance during the dry period on the occurrence of parturient paresis in cows fed excess calcium. J. Anim. Sci. 70:1238-1250.

Vagnoni, D. B., and G. R. Oetzel. 1998. Effects of dietary cationanion difference on the acid-base status of dry cows. J. Dairy Sci. 81:1643-1652.

Wildman, E. E., G. M. Jones, P. E. Wagner, R. L. Boman, H. F. Trout Jr., and T. N. Lesch. 1982. A dairy cow body condition scoring system and its relationship to selected production characteristics. J. Dairy Sci. 65:495-501. 